() Манжалій Е.Г., 2021

doi:10.37321/immunology.2021.3-05

УДК: 61-616.7

\title{
РОЛЬ ГЛІЦИРІЗИНУ У ЛІКУВАННІ ГЕПАТОРЕНАЛЬНОГО СИНДРОМУ
}

\author{
МАНЖАЛІЙ Е.Г. \\ Національний медичний університет імені О.О. Богомольця \\ Київ, Україна
}

\section{ВСтуп}

Печінка є основою системи фільтрації людини, яка перетворює токсини в продукти життєдіяльності, очищає кров і метаболізує поживні речовини та ліки.

Наприклад, парабени широко використовуються в косметиці, фармацевтиці, харчових продуктах та напоях в якості антимікробних агентів і консервантів. Другий найбільш поширений інгредієнт в косметиці.

Інтоксикація може провокувати розвиток багатьох хронічних мультифакторіальних захворювань та синдромів, що характеризуються хронічною втомою, м'язовою слабкістю, порушенням розумових функцій і безліччю інших станів.

Схожі за своїм впливом і ксенобіотики, які пригнічують функціональну активність мітохондрій. Токсичні сполуки активують МРТР (mitochondrial permeability transition poze), інгібують комплекс I респіраторного ланцюга і реплікацію ДНК мітохондрій. Основна маса токсичних сполук $є$ жиророзчинними молекулами. Водорозчинні молекули виводяться з організму з сечею, жиророзчинні сполуки не можуть виділятись сечовивідною системою, замість цього вони приєднуються до ліпідів клітинних мембран і легко проникають всередину клітин, де можуть накопичуватися і мати цитотоксичну дію. Токсичні сполуки можуть продовжувати впливати на організм і впливати на тканини в більш високих концентраціях, ніж існують у зовнішньому середовищі.

Мета. Проаналізувати роль печінки в процесах детоксикації організму, узагальнити програми детоксикації, які будуть найбільш сприятливими для відновлення роботи печінки.

Матеріали та методи. Бібліографічний проведено теоретичний аналіз та здійснено узагальнення даних літератури. При дослідженні використано опис та аналіз.

Результати та їх обговорення. Домінуючу роль у розвитку печінкової енцефалопатії відіграють аміак та меркаптани. Аміак утворюється у товстій кишці із продуктів білкового розпаду під дією амонієгенної мікрофлори, надходить по ворітної вени в печінці, де в нормі більша його частина включається в орнітиновий цикл, кінцевим продуктом якого є сечовина.
Аміак, що не включився в цикл сечовини, захоплюється перивенозними гепатоцитами, В яких з різних аміно- і кето-кислот та аміаку під дією глутамінсинтетази утворюється глутамін.

Ці два механізми служать для запобігання попаданню токсичного аміаку в системний кровотік. При ПЕ швидкість метаболізму аміаку та інших токсинів у печінці значно знижується. Крім того, аміак потрапляє в загальний кровотік по портокавальних анастомозах, при цьому виключається з печінкового метаболізму.

Аміак - ендогенний токсичний метаболіт, утворюється в результаті дезамінування амінокислот в печінці, синтезується уреазпозитивною мікрофлорою кишечника, утворюється в м'язовій тканині при фізичному навантаженні та розпаді глутаміну в тонкій кишці і абсорбується в нирках при гіпокаліємії.

Детоксикація з'єднань аміаку відбувається переважно шляхом його зв'язування в орнітиновому циклі в мітохондріях перипортальних гепатоцитів. Основна кількість аміаку знешкоджується в печінці, але при пошкодженнях печінки порушуються процеси детоксикації, знижується активність орнітинового циклу. Призводить до підвищення концентрації амонію в крові і його подальшого накопичення.

Фактори ризику для НАЖБП встановлені наступні: високоглікемічний раціон харчування, малорухливий спосіб життя, надлишкова вага/ ожиріння, резистентність до інсуліну та цукрового діабету 2 типу, прийом лікарських засобів (гормони, Метотрексат, антиретровірусні засоби). До нових факторів ризику належать: саркопенія, гіпотиреоз, гіперурикемія, окислювальний стрес, хронічне обструктивне захворювання легень, синдром полікістозу яєчників, інфекція Helicobacter pylori, мітохондріальна дисфункція.

Система детоксикації або біотрансформації ксенобіотиків включає 2 етапи: фазу біоактивації 1 і фазу кон'югації 2.

Комплексна інтегрована система для видалення різноманітних токсичних сполук в організмі призначена для перетворення жиророзчинних токсикантів в водорозчинні молекули, після чого перетворені токсичні сполуки можуть безпосередньо виводитися через ниркові канальці або жовчний міхур. 
Реакції фази 1 каталізуються численними ензимами родини цитохрому Р450 (CYP 450). Ензими CYP 450 мають широку специфічність, а в якості кофактору в процесі перетворення кисню в гідроксильну групу для жиророзчинних токсикантів використовують відновлену форму нікотінамін-аденін-динуклеотид (NADH).

Фаза детоксикації 1 включає групу з 50-100 ферментів, яка називається цитохром Р-450. Кожен з цих ферментів взаємодіє з певним типом хімічних речовин. Активність різних ферментів цитохрому Р-450 генетично детермінована і значно варіюється у різних людей. Речовини, що підвищують рівень і надмірну активність P450, називаються індукторами, а ті, що знижують - інгібіторами. Властивості індукторів мають барбітурати, алкоголь, кофеїн, нікотин, стероїди, насичені жири, пестициди. Як інгібі- тори виступають: левоміцетин, циметидин, тетурам, сілібор. Саме в гепатоцитах відбувається перетворення ксенобіотиків в розчинні сполуки, які потім видаляються з організму з жовчю або 3 сечею [1].

Процес детоксикації в печінці включає два послідовних етапи: 1 фаза - окислення, відновлення, гідроксилювання і гідроліз ксенобіотиків до проміжних метаболітів. 2 фаза - кон'югація, метилювання, сульфатація, ацетилювання і глюкуронізація проміжних продуктів до кінцевих розчинних продуктів. Залежно від хімічного складу і властивостей, різні ксенобіотики (канцерогени, лікарські препарати, наркотичні речовини) піддаються різним біохімічним реакціям.

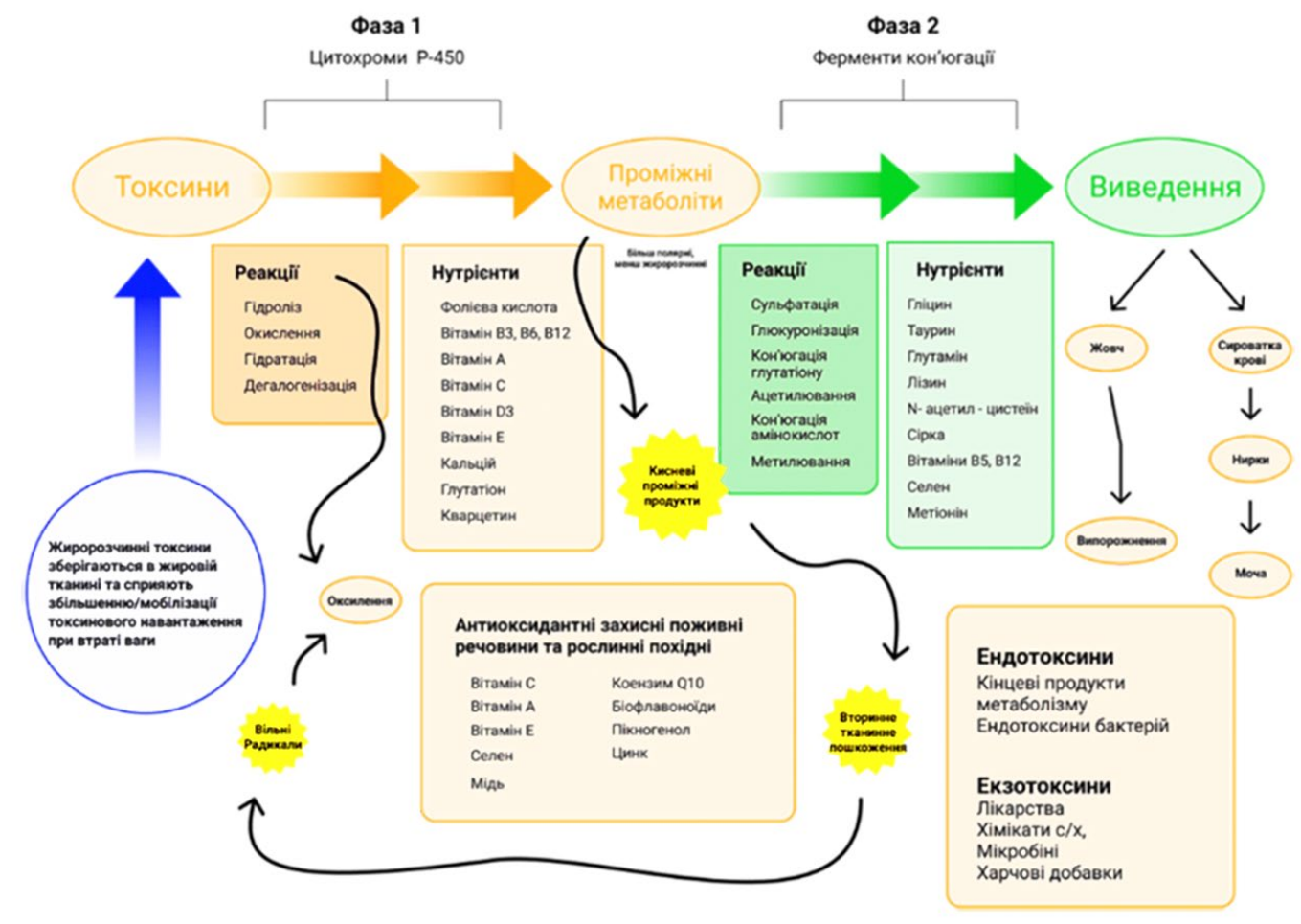

Мал 1. Узгоджена взаємодія реакцій біотрансформації фаз 1 і 2

Природні харчові субстанції, які можуть активувати 1 фазу детоксикації: броколі, брюссельська капуста, кмин і насіння кропу. Нутрієнти, що активують фазу 1: ніацин, вітамін В1 та вітамін С.

Активність ферментів фази детоксикації 2 з віком знижується. Для ефективності фази детоксикації 2, клітинам печінки необхідна сірка, таурин, цистеїн, гліцин, глютамін, холін, інозитол.

Джерелами природних сполук сірки є яйця, овочі сімейства хрестоцвітих (броколі, білокачанна капуста, брюссельська капуста, цвітна капуста), часник, ріпчаста цибуля, цибуля-порей.
Висока активність монооксигеназ може мати небажані наслідки, такі як підвищення токсичності ксенобіотиків, модифікування ендогенних стероїдів та інактивація лікарських сполук.

Електрофільні з'єднання (органічні перекиси, епоксиди, ненасичені альдегіди) стимулюють експресію 2-ї фази інактивації ксенобіотиків, значну частину яких складають ізоферменти - S-трансферази (GST), які каталізують кон'югацію ксенобіотиків і ендогенних електрофільних з'єднань з глутатіоном.

Ферменти GST присутні в різних клітинних компартментах: цитоплазмі, ЕПР і мітохондріях. 
Ксенобіотики індукують експресію генів GSTA14; GSTP1,2; GSTM1-6 і MGST2,3. Поряд з метаболізмом ксенобіотиків, GST беруть участь у біосинтезі простагландинів, лейкотрієнів і стероїдних гормонів [2].

Утворення кон'югатів ксенобіотиків також здійснюють ульфотрансфераза і UDRглюкоронозілтрансфераза (UGT). Ці ферменти модифікують і підвищують розчинність гідрофобних ксенобіотиків і ендогенних ліпофільних сполук (білірубін, стероїди, жовчні кислоти).

Активація транскрипції захисних генів відбувається при контакті клітин з ксенобіотиками та підвищенні рівня ендогенних електрофільних з'єднань у промоторних областях чутливих до ксенобіотиків генів, багато з яких кодують ферменти антиоксидантного захисту і ферменти другої і третьої фаз метаболізму ксенобіотиків, $€$ характерна регуляторна послідовність ARE. ARE також позначають як EpRE i StRE («electrophilic / stress response element»). Вперше ця послідовність була виявлена в промоторних областях генів GSTYa і NQO1. Послідовність ARE служить ділянкою зв'язування транскрипційного фактора Nrf2, який входить у велику групу ДНКзв'язуючих білків bZIP.

Дефіцит вітамінів і мікроелементів, що беруть участь в регуляції детоксикаційної системи печінки, може призводити до небажаних наслідків.

В ході реакцій 2-ї фази детоксикації до проміжних метаболітів приєднуються метильні, сульфгідрильні, ацильні групи, залишки глюкуронової кислоти і амінокислот або глутатіон, в результаті чого вони набувають гідрофільні властивості і можуть бути остаточно видалені $з$ організму [3].

Одним із головних компонентів реакції метилування $€$ S-аденозилметионін (SAM), для синтезу якого потрібен вітамін В12. Для реакцій сульфатації потрібні сірковмісні сполуки, ацетилювання - тіамін (вітамін В1), вітамін С і пантотенова кислота (вітамін В3), сульфоокислення - молібден Мо.

Активність ферментів CYP450 значно варіюється в залежності від генетичних особливостей людини, рівня впливу на нього токсинів і його нутрієнтного статусу. Основним механізмом взаємодії грейпфрута з ліками служить інактивація ферментів сімейства цитохрому Р450, особливо CYP 3A4, який бере участь у метаболізмі багатьох лікарських речовин. Фермент локалізується в епітелії тонкого і товстого кишечника, а також в печінці. Інактивація CYP 3А4 соком грейпфрута відбувається переважно в тонкому кишечнику; однак при вживанні грейпфрута у великих кількостях може знижуватися активність CYP 3 А4 в печінці.
Перелік препаратів, застосування яких в поєднанні з грейпфрутом може вести до побічних ефектів: блокатори кальцієвих каналів, блокатори $\beta$-адренорецепторів, анальгетики, кортикостероїди, естрогени, бензодіазепіни, статини, антибіотики, противірусні (в тому числі що застосовуються при ВІЛ-інфекції), протипухлинні, протиалергічні, психотропні [4].

ГГТ як показник потреби в глутатіоні і токсичної взаємодії. Гамма - глутамілтрансфераза ( $\gamma$-глутамілтранспептидаза) забезпечує обмеження цистеїну через катаболічний «шлях спасіння». Збільшення ГГТ пов'язано з: метаболічним синдромом, фатальними і нефатальними ішемічними хворобами серця (IXC), атеросклерозом, ожирінням печінки, гестаційним діабетом, раком, гіпертонією і товщиною інтими-медії сонної артерії [5]. ГГТ зв'язок зі ступенем запалення і окислення зображено на мал 2.

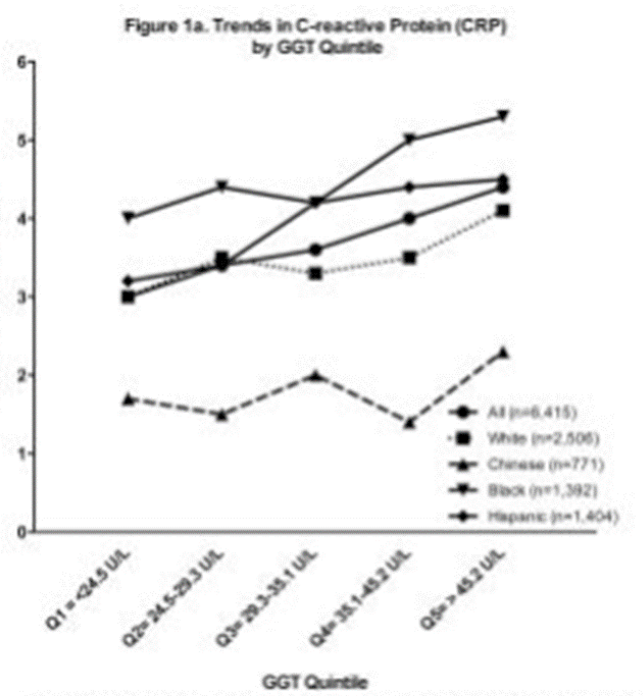

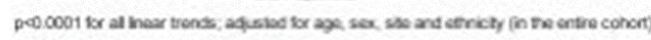

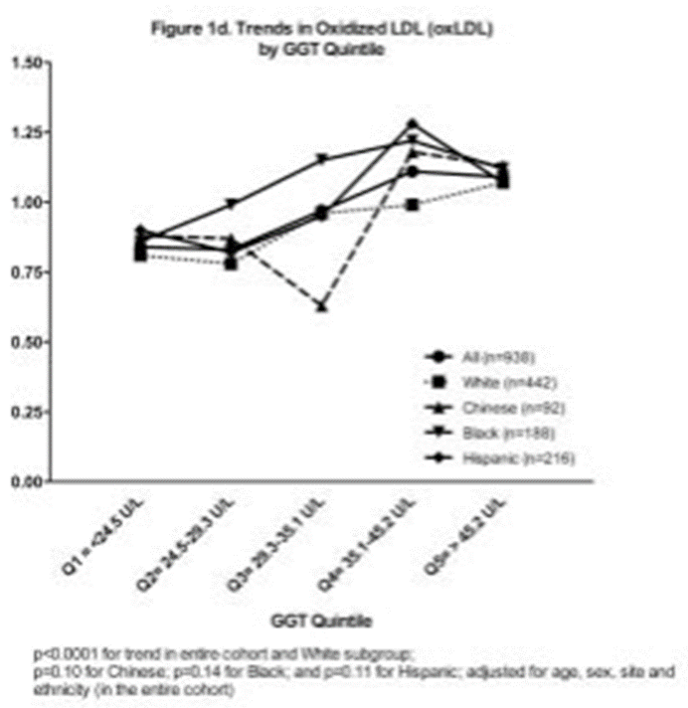

Мал. 2. ГГТ зв'язок зі ступенем запалення і окислення [6] 
Глутатіон має багато ключових ролей, зокрема пряма хімічна нейтралізація атомарного кисню, гідроксильних радикалів та супероксидних радикалів, кофактор для кількох антиоксидантних ферментів, нейтралізація вільних радикалів, викликаних 1-ю фазою метаболізму хімічних токсинів в печінці, ключовий етап II кон'югації, транспортування ртуті з клітин та мозку, регуляція клітинної проліферації та апоптозу, життєво важливий для мітохондріальної функції та підтримання мтДНК, найбільш розповсюджений ендогенний антиоксидант в мозку, що пригнічує запалення.

Глутатіон є трипептидом (цистеїн, гліцин та глутамінова кислота) та містить відносно високі (5 мілімолярні) концентрації в більшості клітин. Існує у відновленому стані (GSH) та окисленому стані (GSSG). Співвідношення визначає окислювально-відновлювальний статус клітини. Здорові клітини в середньому мають співвідношення GSH/ GSSG>100. Співвідношення знижується до 1-10 в клітинах, що піддаються окислювальному стресу. Тіольний буфер, який зберігає сульфгідрильні групи багатьох білків в їх відновленій формі. Виробляється виключно в цитозолі та активно перекачується в мітохондрії.

Глутатіон нейтралізує окиснювачі, що беруть участь в запаленні, зокрема безпосередньо ліквідує різні окиснювачі (супероксидний аніон, гідроксильний радикал, оксид азоту та вуглеводні радикали), каталітично детоксифікує (гідропероксиди, пероксинітрит, перекиси ліпідів) $[7,8]$.

Глутатіон також важливий для захисту мітохондрій. Мітохондрії містять 10-15\% загального клітинного глутатіону, який виробляється в цитозолі. Суттєве зниження рівня глутатіону передує мітохондріальній дисфункції і загибелі нейронів, виявлених при хворобі Паркінсона, припускаючи, що виснаження глутатіону може ініціювати наступні порушення.

Генетичні поліморфізми теж $€$ важливими. Суттєва генетична різниця в синтезі глутатіону, активність ферменту кон'югації глутатіону (навіть наявність). Здатність активувати ГГТ для збільшення рециркуляції глутатіону при дії окислювачів та токсинів.

Було показано, що генетичні поліморфізми в генах GST, GCL і селенопротеїнів впливають на вміст ртуті в організмі людей, що часто споживають рибу (вимірюється як рівень загальної ртуті в еритроцитах), а також рівень ртуті в сечі і волоссі серед стоматологів.

GSH/GSSG відіграє ключову роль в апоптозі. Накопичення GSSG через окислювальний стрес безпосередньо токсичне для клітин, викликає апоптоз шляхом активації шляху SAPK/MAPK. Виснаження глутатіону викликає апоптоз, хоча неясно, чи являються мітохондріальні або цитозольні пули глутатіону вирішальним фактором $[9,10]$.
Низький рівень глутатіону спостерігається при наступних порушеннях: нейродегенеративні захворювання (хвороба Альцгеймера, Паркінсона і Хантінгтона, боковий аміотрофічний склероз, атаксія Фрідрейха), хвороби легень (ХОЗЛ, астма та гострий респіраторний дистрес-синдром), імунні захворювання (ВІЛ, автоімунні захворювання), серцево-судинні захворювання (гіпертонія, інфаркт міокарда, окислення холестерину), хвороби печінки, кістозний фіброз, хронічні вікові захворювання (катаракта, дегенерація жовтої плями, порушення слуху і глаукома), сам процес старіння.

Альфа-ліпоєва кислота збільшує мітохондріальний глутатіон, захищає мітохондрії від окислювачів, покращує мітохондріальну функцію, активізує ферменти Фази II, що забезпечують додаткову підтримку проти окислюючого пошкодження, зменшують вікове зниження пам'яті, користь для профілактики мігрені $[12,13]$.

NAC збільшує рівень глутатіону. Різноманітність як клінічних випробувань, так і даних in-vitro/in-vivo дозволяють припустити, що введення цистеїну у вигляді NAC - це ефективна стратегія для збільшення виробництва глутатіону та внутрішньоклітинного цистеїну. NAC збільшує внутрішньоклітинний глутатіон $[14,15]$.

Глутатіон збільшує виробництво силімарину та альфа-ліпоєвої кислоти. NAC також напряму зв'язує метилртуть та SAMe.

Клітковина важлива для функції детоксикації печінки. Покращення в: жировому індексі печінки (FLI), індексі стеатозу печінки (HIS), індексі НАЖБП, кількості жиру печінки, ГГТ. Користь виникає з 8,8 г фруктової клітковини/добу $[16,17]$.

Бетаїн $є$ активатором в синтезі фосфоліпідів клітинних мембран. Бетаїн може функціонувати як альтернативний донор метильних груп в перетворенні гомоцистеїну в метіонін. Бетаїн може заміщати дефекти в реакціях метилювання, викликані порушенням функціонування фолатного циклу і недоліком вітаміну В12. Бетаїн може також замінювати S-аденозилметионін як донор метильних груп для прямого метилювання фосфатидил-етаноламіну. Цей шлях $€$ альтернативним в утворенні фосфатидилхоліну.

Бетаїн $€$ субстратом холіну і може бути перетворений в DMG шляхом деметилювання, щоб остаточно перетворитися на гліцин. Більшість цих реакцій відбувається в мітохондріях. Реакція деметилювання перетворює гомоцистеїн на метіонін і може бути замінений 5-метил-ТГФ, який може каталізувати метилювання з утворенням ТГФ. Потім метіонін послідовно перетворюється в SAM i, нарешті, в гомоцистеїн з утворенням метіонінового циклу. Гомоцистеїн також може проходити через шлях транссульфурації з утворенням цистатіоніну, цистеїну, таурину або глутатіону. Ферменти, згадані в цьому огляді, показані та позначені в циклі індивідуальними номерами на мал. 4. 


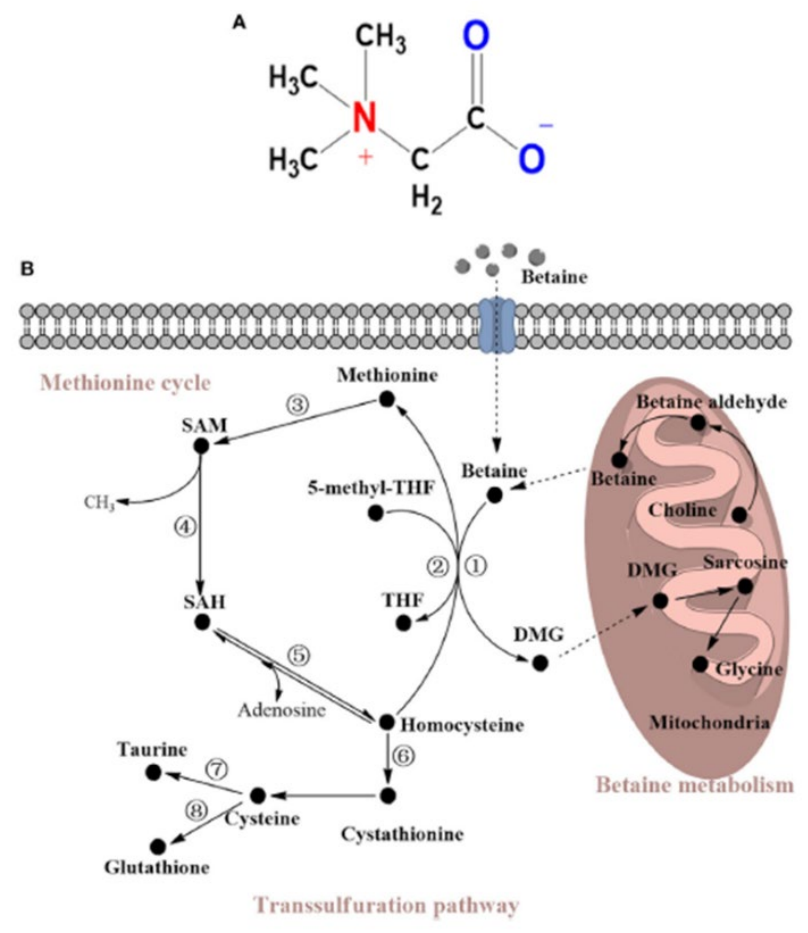

Мал. 3. (А) Молекулярна структура бетаїну. (В) Метаболізм бетаїну та споріднених сірчаних амінокислот (SAA)

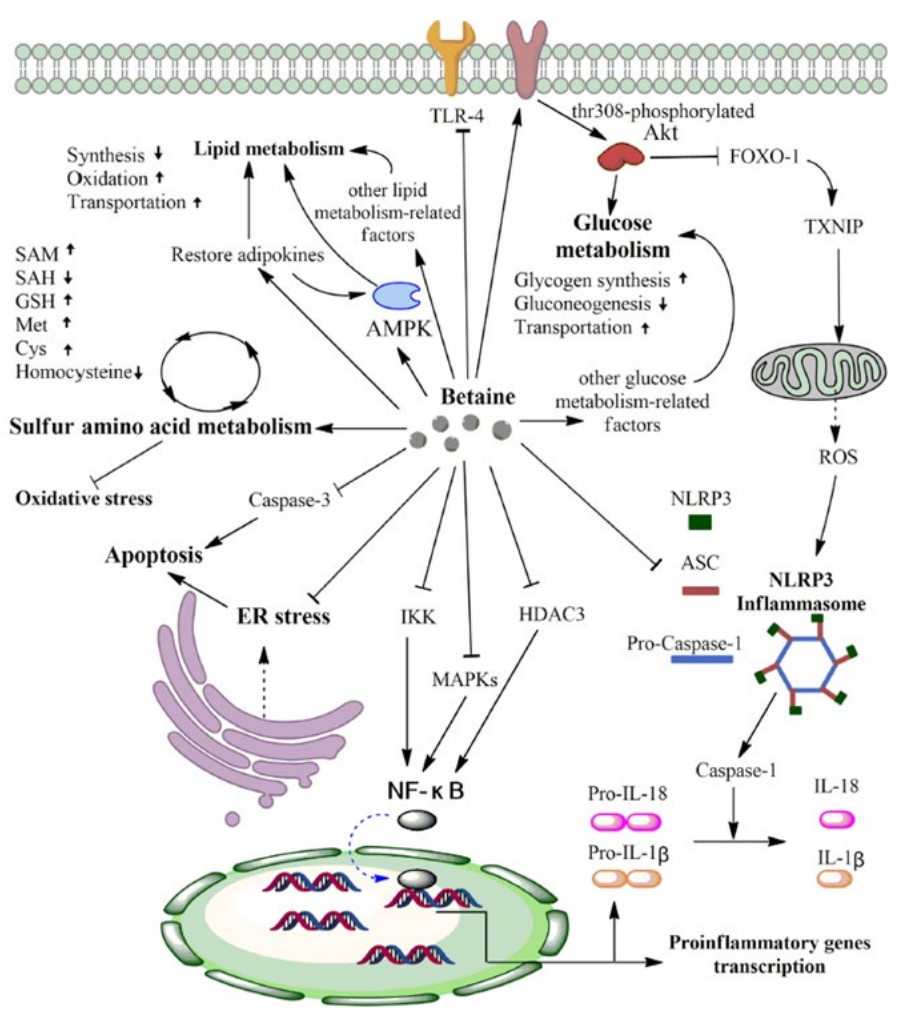

Мал. 4. 1. Бетаїн-гомоцистеїн метилтрансфераза (БГМТ); 2. Метіонінсинтаза (МС); 3. Метіонін аденозилтрансфераза (MAT); 4. SAM - залежні метилтрансферази;

5. S-аденозилгомоцистеїн гідролаза; 6. Цистатіонін - синтаза (CBS); 7. Цистеїндіоксигеназа (CDO); 8. $\gamma$-глутамілцистеїнсинтетаза (ГКС). ТГФ, тетрагідрофолат; SAM, S-аденозил-L-метіонін; SAH S-аденозил-L-гомоцистеїн; DMG, N,N-диметилгліцин [18].
Основні протизапальні механізми бетаїну. По-перше, бетаїн може змінювати різні концентрації сірчаної амінокислоти (SAA), захищаючи метаболізм SAA від окисного стресу. По-друге, бетаїн може інгібувати активність IKK, MAPK, HDAC3 і Toll-подібного рецептора-4 (TLR-4), щоб зменшити регуляцію шляху ядерного фактора кB (NF-кB) і транскрипції прозапальних генів. По-третє, бетаїн може знижувати рівні експресії компонентів запалення NLRP3 (про-каспаза-1, ASC і NLRP3) і інгібувати інфламасому NLRP3, індуковану FOXO-1, шляхом посилення шляху IRS/ Akt. По-четверте, бетаїн значно підвищує активований АМРК, відновлює адипокіни, які можуть активувати AMPK, і активує інші фактори, пов'язані з ліпідним обміном, для регулювання ліпідного обміну. По-п'яте, з одного боку, бетаїн підвищує фосфорильований IRS, який фосфорилює Akt на треонін 308, щоб покращити метаболізм глюкози. 3 іншого боку, бетаїн може впливати на інші фактори, пов'язані з метаболізмом глюкози, покращуючи метаболізм глюкози. По-шосте, бетаїн може інгібувати каспазу-3, щоб зменшити апоптоз і відновити стрес ендоплазматичної мережі (ER). Akt, протеїнкіназа B; AMPK, АМР-активована протеїнкіназа; FOXO-1, вилковий ящик O1; TXNIP, білок, що взаємодіє з тіоредоксином; АФК, активні форми кисню; ІКК, кіназа, що індукує ядерний фактор/кіназа ІкВ; МАРК, протеїнкінази, активовані мітогеном; HDAC3, гістон деацетилази 3. SAM, S-аденозил-L-метіонін; SAH S-аденозил-L-гомоцистеїн; GSH, глутатіон; Мет, метіонін; Цис, цистеїн.

Фізіологічну роль бетаїну можна визначити як: осмопротектора, як донора метильної групи, як протизапальну дію при різних захворюваннях. Ці ефекти в першу чергу пов'язані із захистом метаболізму від окисного стресу, пригніченням $\mathrm{NF}-\kappa \mathrm{B}$. [18].

\section{ДОДАТОК}

Програми з підтримки детоксикації. Зменшення загального токсичного навантаження і впливу токсикантів; забезпечення повної збалансованої підтримки біотрансформації і реакцій кон'югації; створення умов для здорового травлення і екскреції; забезпечення оптимальних механізмів вироблення енергії під час програми детоксикації; підтримка біотрансформації та детоксикації важких металів; забезпечення донаторами метильних груп для формування шляхів метилюван- 
ня; сприяє посиленню видільних функцій нирок, легень, шкіри, підтримує імунну відповідь, антиоксидантний захист і адаптаційні механізми в організмі. На мал. 5 зображені токсини, які зокрема виводяться з організму з потом.

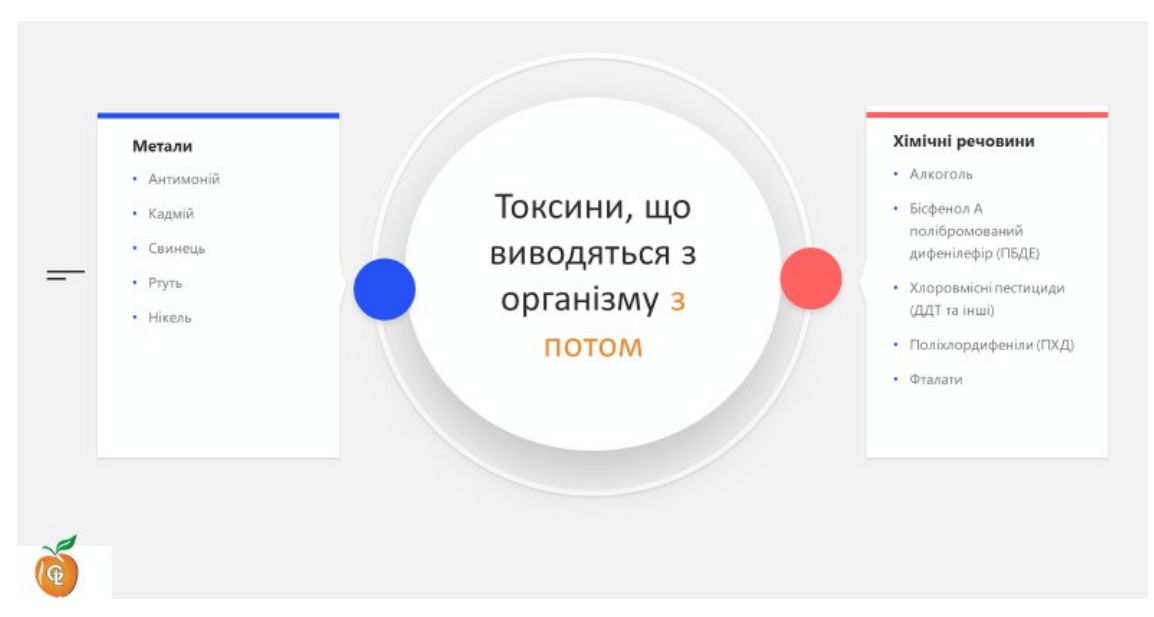

Мал. 5. Токсини, які виводяться з організму з потом

В цілому можна виокремити два варіанти програм детоксикації. I варіант програми детоксикації передбачає застосування OptiCleanse, Nrf2 Activator, Liver Protect.

OptiCleanse підтримує саме природні механізми детоксикації. Спосіб застосування: 2 мірні ложки розвести в 300 мл води 1 раз в день протягом 1 місяця. Склад OptiCleanse передбачає: альфа-ліпоєва кислота (ЛК), D-глюкарова кислота, глутатіон [19].

Альфа-ліпоєва кислота (ЛК) стала звичайним інгредієнтом у полівітамінних формулах, добавках проти старіння і навіть у кормах для свійських тварин. Це добре визначено як терапія для запобігання діабетичній полінейропатії, вона видаляє вільні радикали, хелатує метали та відновлює рівні внутрішньоклітинного глутатіону, які інакше знижуються з віком. Яким чином біохімічні властивості ЛК співвідносяться з його біологічними ефектами? Тут ми розглядаємо молекулярні механізми ЛК, виявлені з використанням моделей клітин та тварин, а також вплив ЛК на людей. Хоча ЛК давно рекламується як антиоксидант, також було показано, що він покращує обробку глюкози та аскорбату, збільшує активність eNOS, активує детоксикацію фази 2.

За допомогою фактору транскрипції, Nrf2 знижує експресію MMP-9 та VCAM-1 за рахунок репресії НФ-каппа-Б. ЛК та її форма, зокрема дигідроліпоєва кислота, можуть використовувати свої хімічні властивості як окислювальновідновлювальну пару для зміни конформації білків шляхом утворення змішаних дисульфідів. Сприятливі ефекти досягаються при низьких мікромолярних рівнях ЛК, що дозволяє припустити, що деякі з її терапевтичних можливостей виходять за межі суворого визначення антиоксиданту.
Поточні клінічні дослідження вивчаються на предмет того, чи роблять ці корисні властивості ЛК відповідним засобом лікування діабету та профілактики судинних захворювань, гіпертонії і запалення [20].

D-глюкарова кислота (GA) - нетоксична природна сполука. Одним із її похідних є потужний інгібітор бета-глюкуронідази D-глюкаро1,4-лактон (1,4-GL). Метою цього дослідження було продемонструвати утворення 1,4-GL із солі D-глюкарату in vivo та визначення її метаболізму, поглинання окремими органами та виведення після перорального введення D-[14C] глюкарату водню калію у людини та самки щурів Sprague-Dawley. 1,4-GL збільшує детоксикацію канцерогенів та промоторів/прогресорів пухлин, інгібуючи бета-глюкуронідазу та запобігаючи гідролізу їх глюкуронідів.

Глутатіон - це трипептид (цистеїн, гліцин і глутамінова кислота), що міститься в дивно високих рівнях - 5 мілімолярних - у більшості клітин. Він відіграє вирішальну роль у захисті клітинних макромолекул від ендогенних та екзогенних активних форм кисню та азоту. Хоча він безпосередньо гасить деякі вільні радикали, можливо, більш важливим є те, що він безпосередньо бореться з причинами окисного стресу, такими як ртуть і СОЗ. Глутатіон бере участь у детоксикації як ксенобіотиків, так і ендогенних сполук.

Він полегшує виведення з клітин $(\mathrm{Hg})$, полегшує виведення з організму (CO3, Hg) і безпосередньо нейтралізує (СО3, багато окислювальних хімічних речовин). Глутатіон сприяє транспортуванню токсинів через плазматичні мембрани щонайменше 4 різними механізмами, найважливішим з яких є утворення S-кон'югатів глутатіону. Низький рівень активності глутатіону 
та/або трансферази також пов'язаний 3 хронічним впливом хімічних токсинів та алкоголю, впливом кадмію, СНІД/ВІЛ, дегенерацією жовтої плями, хворобою Паркінсона та іншими нейродегенеративними розладами.

Глутатіон безпосередньо поглинає різноманітні окислювачі: супероксидний аніон, гідроксильний радикал, оксид азоту та радикали вуглецю. Глутатіон каталітично детоксикує: гідропероксиди, пероксинітрити та перекиси ліпідів. Інший спосіб, яким глутатіон захищає клітини від окисників, - це переробка вітамінів С і E [21].

Nrf2 Activator - це ексклюзивна формула, призначена для активації генетичного шляху Nrf2. Цей шлях регулює виробництво важливих молекул, які передають антиоксидантну активність, таких як глутатіон і супероксиддисмутазу (SOD). Регулює виробництво детоксикаційних ферментів, включаючи S-глутатіонтрансферазу і пригнічує сигнальні фактори, такі як NF-B. Приймати по одній капсули в день 1 місяць [22].

Хіміопрофілактичний агент сульфорафан це ізотіоціанат, отриманий з овочів сімейства хрестоцвітих. Активація транскрипції II фази детоксикації, регульованої елементом антиоксидантної відповіді (ARE), та антиоксидантних генів за допомогою індукції фактора-2, пов'язаного з фактором транскрипції NF-E2 (Nrf2), вважається основним механізмом його хіміопрофілактичної дії. Клітинний рівень Nrf2 строго регулюється протеолізом за допомогою Cullin3 (Cul3)/ Kelch-подібного ЕСН-асоційованого білка 1 (Кеар1)-залежного поліубіквітінірованія. Сульфорафан є електрофілом, який може реагувати з тіолами білка з утворенням тіоноацильних аддуктів і, як вважають, впливає на залишки Суs у Кеар1 білку.

Крім того, сульфорафан може впливати на активність різних внутрішньоклітинних кіназ фосфорилування білків Nrf2, який диктує ядерно-цитоплазматичний транспорт Nrf2 або модулює стабільність білка Nrf2. Цей огляд призначений для короткого пояснення механізму регулювання експресії білка Nrf2 за допомогою лігази Cul3/Keap1 E3 і для можливої ролі посттрансляційних модифікацій клітинних білків Кеар1 або Nrf2 за допомогою сульфорафану в регуляції ARE-залежної активації генів [23].

Усвідомлення того, що нехарчові молекули харчового походження можуть модулювати експресію генів та впливати на внутрішньоклітинні молекулярні механізми, призвело до появи таких областей, як нутрігеноміка та нутрігенетика. Мета цього огляду - описати властивості нутрігеномних активаторів фактора транскрипції Nrf2 (ядерний фактор, пов'язаний 3 еритроїдом 2, фактор 2), порівнюючи потенціал сульфорафану та інших фітохімічних речовин для демонстрації клінічної ефективності як додаткові лікар- ські засоби. Отриманий з броколі сульфорафан з'являється як фітохімічна речовина з цією здатністю, пероральними дозами, здатними сприятливо модифікувати гени, пов'язані з хіміопрофілактикою. Порівняно з широко застосовуваними фітохімічними добавками, такими як куркумін, силімарин і ресвератрол, сульфорафан більш ефективно активує Nrf2, щоб викликати експресію батареї цитопротекторних генів. Завдяки своїй ліпофільній природі та низькій молекулярній масі, сульфорафан демонструє значно більш високу біодоступність, ніж дієтичні добавки на основі поліфенолів, які також активують Nrf2.

Активація Nrf2 індукує цитопротекторні гени, такі як ті, які відіграють ключову роль у клітинних захисних механізмах, включаючи окислювально-відновний статус та детоксикацію. I його висока біодоступність і значна індукційна здатність Nrf2 сприяють терапевтичному потенціалу добавок, що виробляють сульфорафан [24].

Куркумін, жовтий пігмент Curcuma longa, $€$ основним компонентом куркуми і зазвичай використовується як приправа і харчовий барвник. Виявляє протизапальні, протипухлинні та антиоксидантні властивості. Тому в цьому дослідженні досліджували вплив харчових добавок куркуміну на активність антиоксидантних та метаболізуючих ферментів фази II, що беруть участь у детоксикації, та кількісно визначали виробництво активних форм кисню у мишей-самців ddY. Харчова добавка куркуміну (2\%, w/v) самцям мишей ddY протягом 30 днів значно збільшили активність глутатіонпероксидази, глутатіонредуктази, глюкозо-6-фосфатдегідрогенази та каталази до 189\%, 179\%, 189\% і 3 і 18 134\%, 167\% і $115 \%$ у нирках відповідно, порівняно з відповідним контролем, який отримував нормальну дієту $(P<0,05-0,001)$.

Паралельно з цими змінами, годування мишей куркуміном також призвело до значного посилення активності ферментів, які метаболізують фазу 2, а саме глутатіон-S-трансфераза та хіноредуктаза в 1,7 та 1,8 рази в печінці та в 1,1 та 1,3 рази в нирках, відповідно, порівняно з відповідним контролем, який отримував нормальну дієту $(\mathrm{P}<0,05-0,01)$.

Загалом підвищення активності антиоксидантних і метаболізуючих ферментів фази 2 було більш виражено в печінці порівняно з нирками. Індукція куркуміном таких детоксифікуючих ферментів передбачає потенційну цінність цієї сполуки як захисний агент проти хімічного канцерогенезу та інших форм електрофільної токсичності. Значення цих результатів може бути пов'язане з хіміопрофілактичною дією куркуміну проти раку в різних органах-мішенях [25].

Множинні переваги птеростильбену в лікуванні та профілактиці захворювань людини пояснюються його антиоксидантними, проти- 
запальними та антиканцерогенними властивостями, що ведуть до поліпшення функції нормальних клітин та інгібування злоякісних клітин $[26,27]$.

Лікування екстрактом чорниці та РМ на аналогічних моделях захворювань дало паралельні результати, можливо, через антиоксидантну активність та основні механізми птеростильбену. Докази, представлені в цьому огляді, показують, що птеростильбен знижує окисний стрес (OS) та виробництво активних форм кисню (ROS), таких як перекис водню (H2O2) та супероксид-аніон (О2-), які беруть участь в ініціації та патогенезі декількох хворобливих процесів [28].

Крім того, різні клітинні лінії, оброблені птеростильбеном, показали підвищену експресію антиоксидантів каталази, загального глутатіону (GSH), глутатіонпероксидази (GPx), глутатіонредуктази (GR) та супероксиддисмутази (SOD) [29].

Чай, сушене листя видів Camellia sinensis ciмейства theaceae, є популярним напоєм, щорічне виробництво якого становить три мільярди кілограмів у всьому світі [30].

Зелений чай - це неокислений і неферментований продукт, який одержують шляхом сушіння свіжого листя (обсмажування) при високих температурах для інактивації окисних ферментів. Зелений чай містить кілька поліфенолів чаю, в першу чергу катехіни зеленого чаю (GTC), на частку яких припадає 30-40\% твердих речовин, що екстрагуються, висушеного листя зеленого чаю.

Катехіни чаю включають (-) епігалокатехінгаллат (EGCG), (-) епікатехінгаллат (ЕКГ), (-) епікатехін (EC) та (-) епігаллокатехін (EGC) [21], серед яких EGCG є найбільш поширеним, біологічно активним і найбільш вивченим. Відомо, що GTC збільшують кількість антиоксидантних ферментів у крові та діють як антиоксиданти для видалення ROS, таких як супероксид, перекис водню (H2O2) та гідроксильні радикали [31, 32].

В останні десятиліття GTC продемонстрували здатність пригнічувати вільні радикали, що генеруються окислювальними токсикантами навколишнього середовища [33] і, отже, зменшити опосередковане токсикантом цитологічне ушкодження, опосередковане мутацією ушкодження ДНК, рак та апоптоз.

Liver Protect (N-ацетил-L-цистеїн, як ключовий компонент глутатіону, альфа-ліпоєва кислота, силімарин, селен). Приймати по одній капсулі 2 рази на день.

NAC є відновником, сильнішим, ніж цистеїн і GSH, демонструючи більш негативний окислювально-відновний потенціал у 63 і 106 мВ порівняно з напівмікрокомбінованим електродом Orion 9103BN, ніж окислювально-відновна пара GSH/GSSG і Cys/Cys-Cys, відповідно [34].
Що стосується прямої елімінації активних форм кисню та азоту (RONS) [35], NAC швидко реагує з радикалами, які сильно окиснюються, при рН 7 і кімнатній температурі, наприклад НО. $(1,36 \times 1010 \mathrm{M}-1 \cdot \mathrm{s}-1)$, діоксид азоту (NO $2 \cdot)$ $(\approx 1,0 \times 107 \mathrm{M}-1 \cdot \mathrm{s}-1)$ і карбонатний радикал $($ CO $3 \cdot-)(\approx 1,0 \times 107 \mathrm{M}-1 \cdot \mathrm{c}-1)$ [36].

Таким чином, NAC діє при детоксикації АФК, що виробляється лейкоцитами [37], і здатний хелатувати перехідні метали, такі як $\mathrm{Cu} 2+$, $\mathrm{Fe} \mathrm{3+,}$ і важкі метали, такі як Cd 2+ , Hg 2+ і Pb 2+ [38], насамперед через свій тіоловий бічний ланцюг утворювати комплекси, які легко виводяться 3 організму, видаляючись із внутрішньо- та позаклітинного середовища [36]. При фізіологічному pH NAC може хелатувати Hg 2+ i, таким чином, діяти як антидот проти отруєння $\mathrm{HgCl} 2$ [39].

Хоча NAC має здатність безпосередньо поглинати вільні радикали, постійна швидкість реакції з АФК є меншою, ніж щодо антиоксидантних ферментів, таких як SOD, CAT і GPx [40]. Таким чином, пряма елімінація радикалів не настільки важлива, як її антиоксидантна активність.

NAC, що споживається перорально, всмоктується в шлунку і кишечнику і доставляється в печінку через ворітну вену. У печінці NAC швидко інтегрує пептиди для утворення білків і різноманітних метаболітів [34]. У плазмі NAC може бути присутнім як у відновленому, так і в різних окислених формах. Він може окислюватися до дисульфіду, N, N'-діацетилцистину, і він може реагувати з іншими низькомолекулярними тіолами, такими як Cys i GSH, утворюючи змішані дисульфіди. Крім того, NAC може зазнавати окислювально-відновних реакцій з тіоловими групами білків плазми і окислюватися [35].

NAC майже повністю всмоктується, при пероральному введенні щурам лише $3 \%$ радіоактивності 35 S-NAC виділяється з калом, що вказує на те, що всмоктування NAC та його метаболітів майже повне. Дослідження метаболізму з 35 S-NAC на щурах показало, що Cys i Cys-Cys були основними метаболітами в печінці, а неорганічний сульфат був основним продуктом виведення з сечею. Від 13\% до 38\% пероральної дози радіоактивного NAC виявляється в сечі через 24 години. Крім того, невелика кількість таурину і сульфати також виявляються в сечі [41].

NAC захищає астроцити від втрати клітин, опосередкованої інгібітором протеасоми. Первинні кортикальні астроцити обробляли носієм (диметилсульфоксидом) або діапазоном концентрацій MG132 у присутності 3 мM NAC або носія (еквівалент за об'ємом Н2О). (А) Життєздатність визначали через 48 годин шляхом сліпого підрахунку ядер Hoechst + [42]

Швидке введення NAC $€$ стандартом лікування для запобігання ураження печінки при 
передозуванні AРАP. Введений NAC перетворюється шляхом метаболізму першого проходження в цистеїн, який необхідний для поповнення внутрішньоклітинного трипептиду, що містить цистеїн (I- $\gamma$-глутаміл-І-цистеїніл-гліцин), широко відомого як GSH. GSH виснажується під час детоксикації надмірної кількості АРАР. Якщо він не поповнюється швидко, виникає серйозне ураження печінки [43].

II варіант програми детоксикації передбачає застосування XenoProtX.

XenoProtX - це комплексна формула, яка забезпечує збереження 1-ї і 2-ї фаз детоксикації печінки від токсичних речовин з навколишнього середовища, ендокринних порушень, метаболітів естрогену, ксеноестрогенів.

Додатково підтримуе антиоксидантну активність протягом всього процесу детоксикації. Мікроелементи, фітонутрієнти і активовані кофактори забезпечують додаткову підтримку для виробництва енергії, захисту клітин і функції печінки під час важливих процесів біотрансформації метаболізму (5-метилтетрагидрофолієву кислоту, селен (у виді метилселеноцистеїну, поліфенолів та катехинів зеленого чаю)). До складу входять: альфа-ліпоєва кислота, $\mathrm{N}$-ацетил-L-цистеїн, кверцетин, екстракт куркуми, транс-ресвератрол, транс-птеростильбен та глюкорафанін. Приймати по 2 капсули на день 2 місяці після сніданку. До складу входить, зокрема, кверцетин та ресвератрол.

Кверцетин пригнічує індуковану ЛПС продукцію окислювача та експресію молекули адгезії, індукуючи активацію Nrf2 та експресію антиоксидантного ферменту, яка частково опосередковується р38; а інгібуючий ефект кверцетину на експресію молекули адгезії зумовлений не пригніченням активації NF-кB, а натомість завдяки антиоксидантно-незалежним ефектам НО-1 [44].

Ресвератрол може викликати протизапальні властивості, пригнічуючи виробництво ROS та оксиду азоту (NO). Окислювальний стрес, спричинений накопиченням АФК, відіграє роль у розвитку запалення при широкому спектрі захворювань, таких як хронічне запалення та рак.

Було виявлено, що ресвератрол здатний сильно пригнічувати генерацію NO в активованих макрофагах, а також сильно знижувати кількість цитозольно-індуцибельного білка синтази оксиду азоту (iNOS) та стабільні рівні мРHК. Добавка ресвератролу з їжею також може ефективно усувати вільні радикали, посилювати активність SOD, CAT та GPX. Показали, що цитопротекторний ефект ресвератролу обумовлений переважно зменшенням мітохондріальних АФК. Нещодавнє дослідження, здійснене Kortam et al. показало, що ресвератрол збільшує антиоксидантну та протизапальну активність печінки щодо хронічної непередбачуваної депресії, спричиненої помірним стресом, на тваринній моделі, що пояснюється нормалізацією загальної антиоксидантної здатності, глутатіону, малонового діальдегіду (MB), NDA, мієлопероксидази.

Крім того, ресвератрол пригнічував експресію MPHK iNOS та експресію білка в LPSстимульованих клітинах кишечника дозозалежним чином, що призводило до зниження продукції NO. Так само ресвератрол, залежно від дози, інгібував експресію iNOS та IL-6 в оброблених LPS клітинах RAW264.7, а отже, пригнічував продукцію NO та секрецію IL-6 [45].

\section{ВИСНОВКИ}

Перспективи. Науковій спільноті ще потрібно вдосконалювати існуюче лікування і продовжувати пошук нових методик лікування та профілактики належної роботи детоксикаційної функції печінки.

\section{ЛITEPATУPA}

1. Kanazawa S. et al., 2001; Mahgoub AA, 2002; Okura T. et al., 2008; Seidegård J. et al., 2009 року; Nieminen TH et al., 2010),D.G. Bailey i співавторів (2013).

2. Jo SK, Lee et al. Serum gamma-glutamyl trensfetase activity predicts future development of metabolic syndrome defined by 2 different criteria. Clin Chim Acta. 2009 May;403(1-2):234-40

3. Kazkova M., et al. The RISC Investigators. Fatty liver index, gamma-glutamiltransferase and risk of cancer in a cohort of 545,460 persons - the Swedish AMORIS study. Eur J Cancer. 2011 Sep;47(13)2033-41

4. Lee $D H$, et al. Gamma-glutamiltransferase is a predictor of incident diabetes and hypertension: the Coronary Artery Risk Development in Young Adults(CARDIA). Study Clin Chem. 2003 Aug;49(8):1258-66

5. Eroglu S., et al. Association between serum gamma-glutamiltransferase activity and carotid intima-media thickness. Angiology.2011 Feb;62(2):107-10

6. Ryan D Bradley, Annette $L$ Fitzpatrick, David $R$ Jacobs Jr, et al. Linkage between $\gamma$-glutamyltransferase (GGT) and biomarkers of atherosclerosis: poorly centric atherosclerosis (MESA). Atherosclerosis. 2014 Apr; 233 (2): 387-93

7. Biswas SK, Rahman | Biswas SK, Rahman I. Ecological toxicity, redox signaling and pneumonia: the roll of glutathione. Mol Aspects Med. 2009 Feb-Apr; 30 (1-2): 60-76

8. Townsend DM, Tew KD, Tapiero H. Townsend $D M$, Tew, KD, Tapiero $H$. The importance of glutathione in human disease. Biomed Pharmacother. 
9. Filomeni G., et al. Activation of C-Jun-N-terminal kinase is required for apoptosis triggered by glutathione disulfide in neuroblastoma cells. Free Radic Biol Med 2005; 39: 345-354

10. Mari M., et al. Mitochondrial glutathione, a key survival antioxidant. Antioxid Redox Signal. 2009 Nov; 11(11):2685-700

11. Hagen T.M, Ingersoll $\mathrm{R} T(\mathrm{R})$-alpha-lipoic acid-supplemented old rats have improved mitochondrial function, decreased oxidative damage, and increased metabolic rate 1999 Feb;13(2):411-8. doi: 10.1096/fasebj.13.2.411.

12. Delphine Magis, Anna Ambrosini, Peter Sándor, Jean Jacquy, Patrice Laloux, Jean Schoenen A randomized double-blind placebo-controlled trial of thioctic acid in migraine prophylaxis Headache 2007 Jan;47(1):52-7.

13. AEWagner, IMA Ernst, MBirringer, OSancak, $L$ Barella, G Rimbach A combination of lipoic acid plus coenzyme Q10 induces PGC1 $\alpha$, a master switch of energy metabolism, improves stress response, and increases cellular glutathione levels in cultured $\mathrm{C} 2 \mathrm{C} 12$ skeletal muscle cells Oxid Med Cell Longev. 2012:835970. doi: 10.1155/2012/835970. Epub 2012 May 9.

14. Seetal Dodd, Olivia Dean, David L Copolov, Gin $S$ Malhi, Michael BerkN-acetylcysteine for antioxidant therapy: pharmacology and clinical utilityExpert Opin Biol The. 2008 Dec;8(12):195562. doi: $10.1517 / 14728220802517901$.

15. Mohammad Sadegh Soltan-Sharifi, Mojtab Mojtahedzadeh, AtabakNajafi, MohammadReza Khajavi, Mohammad Reza Rouini, Mandana Moradi, Azadeh Mohammadirad, Mohammad Abdollahi Improvement by $\mathrm{N}$-acetylcysteine of acute respiratory distress syndrome through increasing intracellular glutathione, and extracellular thiol molecules and anti-oxidant power: evidence for underlying toxicological mechanisms Hum Exp Toxicol 2007 Sep;26(9):697703. doi: $10.1177 / 0960327107083452$.

16. Raxit J Jariwalla, Jacob Lalezari, Diane Cenko, Sam E Mansour Restoration of blood total glutathione status and lymphocyte function following alpha-lipoic acid supplementation in patients with HIV infection J Altern Complement Med. 2008 Mar;14(2):139-46. doi: 10.1089/acm.2006.6397.

17. Charles S Lieber, Lester Packer S-Adenosylmethionine: molecular, biologi$\mathrm{cal}$, and clinical aspects-an introduction Am $\mathrm{J}$ Clin Nutr. 2002 Nov;76(5):1148S-50S. doi: 10.1093/ajen/76/5.1148S.

18. Guangfu Zhao, Fang He, Chenlu Wu, Pan $L i$, Nengzhang Li, Jinping Deng, Guoqiang Zhu, Wenkai Ren Betaine in inflamma- tion: Mechanistic Aspects and Applications. Front. Immunol., 24 May 2018 | https://doi. org/10.3389/fimmu.2018.01070

19. Kate Petersen Shay, Régis F. Moreau, Eric J. Smith, Anthony R. Smith Alpha-lipoic acid as a dietary supplement: Molecular mechanisms and therapeutic potential. Published online 2009 Aug 4. doi: 10.1016/j.bbagen.2009.07.026

20. Walaszek Z., Szemraj J., Narog M., Adams A.K., Kilgore J., Sherman U., Hanausek M. Metabolism, uptake, and excretion of a $D$-glucaric acid salt and its potential use in cancer prevention. 1997;21(2):178-90.

21. Joseph Pizzorno Glutathione! Integr Med (Encinitas). $2014 \mathrm{Feb}$; 13(1): 8-12.

22. KeumYS. Ann NYAcad Sci. 2011 Jul; 1229:1849. doi:10.1111/j.1749-6632.2011.06092.x

23. Christine A Houghton, Robert $G$ Fassett, Jeff $S$ Coombes Sulforaphane and Other Nutrigenomic Nrf2 Activators: Can the Clinician's Expectation Be Matched by the Reality? Oxid Med Cell Longev. 2016:7857186. doi: 10.1155/2016/7857186. Epub 2016 Jan 6.

24. Mohammad lqbal, Som Datta Sharma, Yasumasa Okazaki, Masayoshi Fujisawa, Shigeru Okada. Dietary supplementation of curcumin enhances antioxidant and phase II metabolizing enzymes in ddY male mice: possible role in protection against chemical carcinogenesis and toxicity. Pharmacol Toxicol. 2003 Jan;92(1):33-8. doi: 10.1034/j.16000773.2003.920106.x.

25. Denise McCormack and David McFadden. A Review of Pterostilbene Antioxidant Activity and Disease Modification. 2013 Apr 4. doi: $10.1155 / 2013 / 575482$

26. Moszczynski P, Slowinski S, Lisiewicz J. [Enzyme deficiency in the lymphocytes of tobacco smokers] Przeglad lekarski. 1989;46:719-22. [PubMed] [Google Scholar]

27. Patel BP, Rawal UM, Shah PM, Prajapati JA, Rawal RM, Dave TK, et al. Study of tobacco habits and alterations in enzymatic antioxidant system in oral cancer. Oncology. 2005;68:511-9. [PubMed] [Google Scholar]

28. Bosetti C, Turati $F$, La Vecchia C. Hepatocellular carcinoma epidemiology. Best practice \& research Clinical gastroenterology. 2014;28:753-70. [PubMed] [Google Scholar]

29. Lixia Chen, Huanbiao Mo, Ling Zhao, Weimin Gao, Shu Wang, Meghan M Cromie, Chuanwen Lu, Jia-Sheng Wang, and ChwanLi Shen. Therapeutic properties of green tea against environmental insults. 2016 May 27. doi: 10.1016/j.jnutbio.2016.05.005. 
30. Yang CS, Landau JM. Effects of tea consumption on nutrition and health. The Journal of nutrition. 2000;130:2409-12. [PubMed] [Google Scholar]

31. Misra A, Chattopadhyay $R$, Banerjee $S$, Chattopadhyay DJ, Chatterjee IB. Black tea prevents cigarette smoke-induced oxidative damage of proteins in guinea pigs. The Journal of nutrition. 2003;133:2622-8. [PubMed] [Google Scholar]

32. Sreekanth KS, Sabu MC, Varghese L, Manesh $C$, Kuttan G, Kuttan R. Antioxidant activity of Smoke Shield in-vitro and in-vivo. The Journal of pharmacy and pharmacology. 2003;55:847-53. [PubMed] [Google Scholar]

33. Hara Y. Green Tea: Health Benefits and Applications. CRC Press; 2001.

34. Noszál B., Visky D., Kraszni M. Population, acidbase, and redox properties of $\mathrm{N}$-acetylcysteine conformers. J. Med. Chem. 2000;43:21762182. doi: 10.1021/jm9909600.

35. Sadowska A.M., Manuel Y.K.B., de Backer W.A. Antioxidant and anti-inflammatory efficacy of NAC in the treatment of COPD: Discordant in vitro and in vivo dose-effects: $A$ review. Pulm Pharmacol. Ther. 2007;20:9-22. doi: 10.1016/j.pupt.2005.12.007.

36. Samuni Y., Goldstein S., Dean O.M., Berk M. The chemistry and biological activities ofN-acetylcysteine. Biochim. Biophys. Acta. 2013;1830: 4117-4129. doi: 10.1016/j.bbagen.2013.04.016.

37. Akca T., Canbaz H., Tataroglu C., Caglikulekci M., Tamer L., Colak T., Kanik A., Bilgin O., Aydin S. The effect of $\mathrm{N}$-acetylcysteine on pulmonary lipid peroxidation and tissue damage. J. Surg. Res. 2005;129:38-45. doi: 10.1016/ j.jss.2005.05.026.

38. Kasperczyk S., Dobrakowski M., Kasperczyk A., Machnik G., Birkner E. Effect of N-acetylcysteine administration on the expression and activities of antioxidant enzymes and the malondialdehyde level in the blood of lead-exposed workers. Environ. Toxicol. Pharmacol. 2014;37:638-647. doi: 10.1016/j.etap.2014.01.024.

39. Oliveira V.A., Oliveira C.S., Mesquita M., Pedroso T.F., Costa L.M., Fiuza Tda L., Pereira M.E. Zinc and N-acetylcysteine modify mercury distribution and promote increase in hepatic metallothionein levels. J. Trace Elem. Med. Biol. 2015;32:183-188. doi: 10.1016/ j.jtemb.2015.06.006.

40. Jones C.M., Lawrence A., Wardman P., Burkitt M.J. Kinetics of superoxide scavenging by glutathione: An evaluation of its role in the removal of mitochondrial superoxide. Biochem Soc. Trans. 2003;31:1337-1339. doi: $10.1042 /$ bst0311337.
41. Bonanomi L., Gazzaniga A. Toxicological, pharmacokinetic and metabolic studies on acetylcysteine. Eur. J. Respir. Dis. Suppl. 1980;111:45-51.

42. Amanda M. Gleixner, Daniel F. Hutchison, Sara Sannino, Tarun N. Bhatia, Lillian C. Leak, Patrick T. Flaherty, Peter Wipf, Jeffrey L. Brodsky, and Rehana K. Leakcorresponding. $\mathrm{N}$-Acetyl-I-Cysteine Protects Astrocytes against Proteotoxicity without Recourse to Glutathione. 2017 Nov. doi: 10.1124/ mol.117.109926

43. Richard Eugene Frye and Michael Berk. Cysteine/Glutathione Deficiency: A Significant and Treatable Corollary of Disease. $2018 \mathrm{Jul}$ 19. doi: 10.1007/978-981-10-5311-5_20

44. Chuan Li, Wei-Jian Zhang, and Balz Frei. Quercetin inhibits LPS-induced adhesion molecule expression and oxidant production in human aortic endothelial cells by p38-mediated Nrf2 activation and antioxidant enzyme induction. 2016 Jun 28. doi: 10.1016/j.redox.2016.06.006

45. Tiantian Meng, Dingfu Xiao, Arowolo Muhammed, Juying Deng, Liang Chen, and Jianhua He1. Anti-Inflammatory Action and Mechanisms of Resveratrol. 2021 Jan 5. doi: 10.3390/molecules26010229

\section{PЕЗЮME \\ РОЛЬ ГЛІЦИРІЗИНУ У ЛІКУВАННІ ГЕПАТОРЕНАЛЬНОГО СИНДРОМУ}

МАНЖАЛІЙЕ.Г.

Національний медичний університет імені О.О. Богомольця Київ, Україна

Вступ. Зважаючи на те, що печінка виконує функцію фільтрації, належна робота обох фаз детоксикації впливає на роботу печінки вцілому та забезпечує цілісний ланцюг роботи. Протягом останніх років, багато продуктів заполонили планету, зокрема токсини, метали, хімікати (неорганічні, розчинники, пластифікатори), синтетичні лікарські засоби, пліснява, тверді домішки, ПАВи, радіація, ендотоксини, хімічні речовини тощо. Зазначені речовини негативно впливають на роботу печінки та порушують цілісний ланцюг роботи фаз детоксикацій. 3 огляду на це, в статті запропоновані програми детоксикації для відновлення роботи печінки.

Мета. Проаналізувати причино-наслідковий зв'язок виникнення та розвитку хвороб печінки у зв'язку з порушенням роботи фаз детоксикацій та узагальнити стратегії лікування на підставі доказової медицини.

Матеріали та методи. Бібліографічний - проведено теоретичний аналіз та здійснено узагальнення даних літератури. При дослідженні використано опис та аналіз.

Результати та їх обговорення. 
Висновки. Контроль за показниками пацієнта, призначення тактики лікування в залежності від типу порушень детоксикаційних функцій печінки, надає можливість стабілізувати стан пацієнта.

Ключові слова: фази детоксикації, глутатіон, програми детоксикації.

\section{PЕЗЮME \\ РОЛЬ ГЛИЦИРРИЗИНА В КОМПЛЕКСНОМ ЛЕЧЕНИИ ГЕПАТОРЕНАЛЬНОГО СИНДРОМА}

Манжалий Э.Г.

Национальный медицинский университет имени А.А. Богомольца

Киев, Украина

Введение. Учитывая, что печень выполняет функцию фильтрации, надлежащая работа обеих фаз детоксикации влияют на работу печени в целом и обеспечивают целостную цепь её работы. В последние годы многие продукты заполонили планету, в частности токсины, металлы, химикаты (неорганические, растворители, пластификаторы), синтетические лекарственные средства, плесень, твердые примеси, ПАВы, радиация, эндотоксины, химические вещества и т.д. Указанные вещества отрицательно влияют на работу печени и нарушают целостную цепь работы фаз детоксикаций. Учитывая это, в статье предложены программы детоксикации для возобновления работы печени.

Цель. Проанализировать причинно-следственную связь возникновения и развития заболеваний печени в связи с нарушением работы фаз детоксикаций и обобщить стратегии лечения на основании доказательной медицины.

Материалы и методы. Библиографический проведен теоретический анализ и осуществлено обобщение данных литературы. При исследовании использовано описание и анализ.

Результаты и их обсуждение.

Выводы. Контроль показателей пациента, назначение тактики лечения в зависимости от типа на- рушений детоксикационных функций печени, дает возможность стабилизировать состояние пациента.

Ключевые слова: фазы детоксикации, глутатион, программы детоксикации.

\section{SUMMARY}

\section{THE ROLE OF GLYCYRRHIZIN IN THE COMPLEX TREATMENT OF HEPATORENAL SYNDROME}

\author{
Manzhalii E. \\ Bogomolets National Medical University \\ Kyiv, Ukraine
}

Introduction. Due to the fact that the liver performs the function of filtration, the proper functioning of both phases of detoxification affect the work of the liver as a whole and ensure a holistic chain of work. In recent years, many products have flooded the planet, including toxins, metals, chemicals (inorganic, solvents, plasticizers), synthetic drugs, mold, solids, surfactants, radiation, endotoxins, chemicals and more. These substances adversely affect the liver and disrupt the whole chain of detoxification phases. With this in mind, the article offers detoxification programs to restore liver function.

Goal. Analyze the cause-and-effect relationship between the occurrence and development of liver disease due to disruption of the detoxification phases and summarize treatment strategies based on evidence-based medicine.

Materials and methods. Bibliographical and theoretical analysis is carried out and a generalization of literature data is carried out. Description and analysis were used in the research.

\section{Results and its discussion.}

Conclusions. Control over the patient's performance, the appointment of treatment tactics depending on the type of disorders of detoxification functions of the liver, provides an opportunity to stabilize the patient's condition.

Key words: detoxification phases, glutathione, detoxification programs

\section{АВТОРСЬКА ДОВІДКА}

\author{
- Манжалій Еліна Георгіївна \\ Національний медичний університет імені \\ 0.О. Богомольця, д.М.Н. \\ Адреса: вул. П. Запорожця, 26, \\ Київ, Україна \\ моб.: +380689227777 \\ E-mail: elinam@ukr.net
}

\author{
- Манжалий Элина Георгиевна \\ Национальный медицинский университет \\ имени А.А. Богомольца, д.м.н. \\ Адрес: ул. П. Запорожца, 26, \\ Киев, Украина \\ моб.: +380689227777 \\ E-mail: elinam@ukr.net
}

\author{
- Manzhalii Elina \\ Bogomolets National Medical University, PhD \\ Address: str. P. Zaporozhets, 26, \\ Kyiv, Ukraine \\ mob.: +380689227777 \\ E-mail: elinam@ukr.net
}

